\title{
THE EFFECT OF BUDGET PARTICIPATION ON BUDGETARY SLACK
}

\author{
Sudirman ${ }^{1}$, Saraswati Erwin ${ }^{2}$, Usman Ernawaty ${ }^{1 *}$ \\ ${ }^{1}$ University of Tadulako, Indonesia \\ ${ }^{2}$ University of Brawijaya, Indonesia \\ *E-mail: ernawatyusman02@yahoo.co.id
}

\begin{abstract}
This research aims to analyze the effect of budget participation on budgetary slack; the influence of organizational commitment on budgetary slack; the influence of organizational culture on budgetary slack; organizational commitment as the pure moderation variable or quasi moderation variable in the influence of budgetary participation on budgetary slack; organization culture as pure moderation variables or quasi moderation variables in the influence of budgetary participation on budgetary slack. This is a descriptive research in which the data are collected through observation, documentation and literature review. The data were analyzed using multiple linear regression analysis. The result of this research exhibited that budgetary participation has a negative influence on budgetary slack. Organizational culture and organizational commitments have negative effects on budgetary slack.
\end{abstract}

\section{KEY WORDS}

Budgetary participation, organizational commitment, organizational culture, budgetary slack.

Budget is one of the vital tools of a company in achieving its goals. Participative budgeting, according to Brownell (1982), is a process that describes how the individuals involved in the budget preparation. It has an influence on the budget targets and rewards upon achieving budgeting target. Budgetary participation is thought to have consequences on attitudes and behaviors of organization members (Murray, 1990). Should the budgetary participation does not run well, it may encourage the individuals to create budgetary slack.

The phenomenon underlying this research is the ambiguous theoretical contradiction in budgetary participation. On one side, budgetary participation does not create budgetary slack (Research conducted by Camman (1976), Dunk (1993), Merchant (1985) and Onsi (1973)). On the other hand, participatory budgeting has a positive relationship with budgetary slack (research conducted by Lowe and Shaw (1968), Young (1985)). The most researchers conducted research on the effect of participatory budgeting on budgetary slack in private sectors, specifically manufacturing company. There are only a few researches conducted on public sectors such as hospitals whereas public sector organizations including central government, public hospitals, state-owned enterprises have different characteristics on budget arrangement and report (Mardiasmo, 2009:7).

Hospitals, especially public hospitals (Bastian, 2010: 11) is one of the types of public sector organizations in Indonesia. It has very different characteristics and environment compared to private hospitals. These differences also exhibit different objectives and goals between the government and private organizations. The main purpose of government organizations is providing services to the public, while private sectors are purposed to optimize organizational profit devoted for the welfare of shareholders. Differences on budget planning and arrangement in public sector and subsidy coming from the central government to regional government create financial dependency which creates budgetary slack. The existence of substantial differences between public and private hospitals will influence the budgeting process. Therefore, a certain mechanism is necessary to manage public's aspiration and increase social service. Under these conditions, the researcher is interested to conduct a research on the public sector, particularly on public hospitals.

This research used organizational commitment and culture as moderating variables in assessing the relations between budgetary participation and budgetary slack. Organizational 
commitment is one of the most important variables in this research as it is the influential factor of the organization in achieving its targets and goals. Individuals with high commitment tend to have positive thoughts and will strive to perform its best for the organization.

Organizational culture is influential on the employees' tendency to cause budgetary slack. Organizational culture is social forces that encourage organization members to perform work activities. Culture in an organization used a dimensional approach that practices the values and beliefs owned by the members of the organization manifested in individuals or groups behavior in an organization.

Based on the research background, the specific issue in this research is on whether budgetary participation, organization commitments, and culture affect budgetary slack and whether organization commitments and culture moderate the influence of budgetary participation on budgetary slack.

\section{LITERATURE REVIEW}

Budgetary slack is the dissidence on the total budget proposed by the employees and the total preferred estimated budget of the company (Anthony and Govindradjan, 2004). According to Young (1985), budgetary slack is an act of decreasing productive capability by the employees when expected to determine their working standards. Hansen and Mowen (2007) argued that in participative budgeting, possible issues may occur such as: the heads of organization or the staffs may either set the budget standard too high or too low; the staffs/employees may possibly carry out budgetary slack/budgetary slack by allocating subordinate resources; pseudo participation.

Participation is a process in which the individuals influence on budget preparation. Their works will be evaluated and may be rewarded for achieving the target (Brownell, 1982). Managerial performances are expected to increase through budgeting participation. This is based on the idea that when objectives or standards are set collectively and agreed upon, the workers will strive to achieve the goals and objectives and will be responsible as they had parts in constructing goals.

Organizational commitment is an individual's commitment toward its company/organization. A person's commitment to the organization is one that guarantees the sustainability of the organization. Mowday et al., in Curtis, Susan, and Wright (2001), stated commitment as the strength of individuals in an organization.

According to Zurnali (2010), organizational commitment is similar to Durkin's opinion (1999:127) stating that organizational commitment is a strong feeling of someone, strong attachment toward the objectives and values of an organization as well as its relation and role toward achieving those objectives.

Hofstede (1994) stated that culture consists of a mental joint program that requires responses from the individuals to its environment. Culture not only out-surfaced behavior but are instilled in each person. Organization culture can be described as values, beliefs, assumption, norms that are valid and agreed upon within the organization as guidance in solving issues. It is in line with Luthans's (1998) opinion stating that organizational cultures are the norms and values that guide the behavior of members of the organization. Strong organizational cultures will support the organization's goals. Weak organizational cultures may inhibit or in contrast with organization's goals. Positive influence means people-oriented organizational cultures will tend to not cause budgetary slack. On the other hand, workoriented organizational cultures will cause high budgetary slack.

This research is a continuation of the research conducted by Usman (2012) about the influence of organizational cultures and asymmetric information toward the relation between budgetary participation on the discrepancy. The results exhibited a positive effect of budget participation on budgetary slack. Lewis and Ernawaty Usman (2011) conducted research on the influence of budget participation on the performance of local government officials. The results of the research exhibited that budgetary participation is positively related to the performance of local government officials. 
Table 1 - Characteristics of employee-oriented and work-oriented organizational cultures

\begin{tabular}{|l|l|}
\hline \multicolumn{1}{|c|}{ Employee-oriented culture } & \multicolumn{1}{c|}{ Work-oriented culture } \\
\hline Important decisions are determined collectively & Important decisions are determined individually \\
\hline The worker is more preferred than the work results & The work result is more preferred than the worker \\
\hline Giving clear work instructions to new employees & Less clear work instructions to new employees \\
\hline Concerned about the personal matters of employees & unconcerned about the personal matters of employees \\
\hline
\end{tabular}

Source: Sulaksono (2005).

Young (1985) empirically examined the influence of personal information on the production capabilities, risk preference, and budgetary slack. The result exhibited that the desire to avoid the risk conducted by staffs participating in the budgeting process, there tends to be possible budgetary slack. These findings suggest that budgetary participation will increase the budgetary slack (positive effect). Merchant (1985) assessed the proposition on how participation will decrease the force causing budgetary slack. Govindarajan (1986) researched on the relation between budgetary participation and budgetary slack which the result exhibited positive relation in uncertain condition and negative relation in a certain condition. Onsi (1973) and Supanto (2010) researched budgetary participation and budgetary slack and found a significant relation which is a negative correlation between budgetary participation and budgetary slack. The results are similar to the research conducted by Camman (1976), Dunk (1993), and Merchant (1985). However, different results from Asringati (2006) exhibited that the budget participation positively related to budgetary slack. Based on the above explanation, the first hypothesis that the researchers propose would be:

$H_{1}$ : Budgetary participation has a negative relation to budgetary slack.

Nouri and Parker (1996) assessed the influence of organizational commitment on the relation between budgetary participation and budgetary slack. The high organizational commitment would reduce the individual's tendency to cause budgetary slack. On the other hand, if the commitment is low, personal needs will be prioritized and the individual would tend to cause budgetary slack. It would cause the target budget will be easier to achieve and has better work assessment. Based on the above explanation, the second and third hypotheses proposed are as follows:

$\mathrm{H}_{2}$ : Organizational commitment has a negative influence on budgetary slack.

$\mathrm{H}_{3}$ : Organizational commitment moderates the influence of budgetary participation on budgetary slack.

Tjahjaning (2001) stated that organizational cultures have a positive influence on the relation of budgetary participation on managerial performance. However, Sardjito (2007), Usman (2012) found that organizational cultures have a negative influence over budgetary participation. This research result is similar to Ritongan (2008). The research conducted by Supanto (2010) exhibited that organizational cultures do not affect budgetary participation either. Supomo and Indrianto (1998) found that there is a positive influence of peopleoriented organizational cultures and negative influence of work-oriented organizational cultures over the effectiveness of budgetary participation in increasing managerial performance. follows:

Based on the above explanation, the fourth and fifth hypotheses proposed are as

$\mathrm{H}_{4}$ : Organizational cultures have a negative relation to budgetary slack.

$\mathrm{H}_{5}$ : Organizational cultures moderate the influence of budgetary participation to budgetary slack.

\section{METHODS OF RESEARCH}

This field research used survey method to collect the field data in order to describe the influence of organizational commitment and organizational cultures on the relation between budgetary participation and budgetary slack. The research design used in this study is an 
explanation (explanatory research) because this research described causal relationships between variables through hypothesis testing.

The populations in this study were all the directors, deputy directors, section heads, heads of the installations and the employees involved in the budgeting process in the Palu's public hospitals. Based on the surveys conducted in five public hospitals in Palu, there were 180 respondents. The researchers used Slovin approach (in Umar, 1999:67), resulting in 124 respondents involved in the research.

The independent variable in this research was budgetary participation, the moderating variables were organizational commitment and culture, and the dependent variable was the budgetary slack. Budgeting participation was measured using 4 instruments adopted from Kenis (1979). Organizational commitment was measured using 9 instruments adopted from Mowday (1979). Organization culture was measured using 8 instruments adopted from Hofstede et al, (1990). Budgetary slack was measured using 6 instruments adopted fro Dunk 1993. All the instruments (questions) were measured using 5 points Likert-scale

The quality of research data is determined by the quality of the instruments used to collect data. The reliability test was conducted to measure a questionnaire which is an indicator of a variable (Jogiyanto, 2007: 52)

The analysis calculations used was multiple regression analysis by using a software called Statistical Product and Service Solutions (Ghozali, 161:2009). The formula is as follows:

$$
\mathrm{Y}=\mathrm{b}_{0}+\mathrm{b}_{1} \mathrm{X}_{1}
$$

Where: $\mathrm{Y}=$ Budgetary Slack, $\mathrm{X}_{1}=$ Budgetary Participation, $\mathrm{b}_{0}=$ constant, $\mathrm{b}_{1}=$ regression coefficient.

MRA is a special application for multiple linear regression in which regression contains elements of interactions (multiplication of two or more independent variables) with the formula:

$$
Y=a+b 1+b 2 \times 1 \times 2 \times 3+b 3+b 4+b 5 \times 1 \times 3 \times 1 \times 2
$$

Where: $\mathrm{Y}=$ the dependent variable, $\mathrm{a}=$ constant, $\mathrm{b} 1-\mathrm{b} 5=$ regression coefficient, $\mathrm{X} 1-\mathrm{X} 3=$ free variable.

Classical assumption test was conducted by the following methods; (1) multicollinearity test was conducted using the Pearson test, as a criterion when the correlation between two variables exceeds 0.8 , then multicollinearity will occur. (2) heteroscedasticity test was conducted to assess whether in the regression model occurred variance inequality from one residual observation to another observation, and (3) normality test which aims to test whether in the regression model, the intruding variable or residual has normal distribution, through observing normal probability plot which compares cumulative distribution and normal distribution (Gujarati, 2006:63).

$\mathrm{F}$ test is a test to exhibit whether all the independent variables in the model have collective influence over independent variables. If the $F$ value calculation result is greater than the value $\mathrm{F}$ according to the table, then $\mathrm{Ho}$ is rejected and $\mathrm{Ha}$ is accepted. The basic assumptions required is the real standard $(\alpha)$ which is $5 \%$. The t-test is a test conducted to test the level of significance of the influence of independent variables individually over dependent variables using real standard $(\alpha)$ which is $5 \%$.

\section{RESULTS OF STUDY}

The results of reliability test using SPSS software exhibited adequate Cronbach's Alpha value. Cronbach's Alpha diatan score of 0.60 was considered quite reliable (Ghozali, 2006: 48). Each variable obtained Cronbach's Alpha value for budget participation $\alpha=0.688$, budgetary slack $\alpha=0.644$, organizational culture at $\alpha=0.641$ and organizational commitment 0,656 . A construct or variable is said to be reliable if the value of Cronbach Alpha> 0.60 (Nunally, 1960). The validity of the test results by means of statistical tests can 
be concluded that all valid variables, evidenced by the all items have Questions Correlated Item-Total Correlation bigger than r table. (Ghozali, 2001: 49).

Multicollinearity is the situation there is a correlation between the independent variables with each other. One way to detect multicollinearity is the Pearson test. As a criterion, the correlation between the two variables exceeds 0.8 exhibits multicollinearity (Gujarati, 2006; 63). Multicollinearity test results exhibited that the correlation between two variables does not exceed 0.8 .

Heteroscedasticity test aims to test whether the regression model occurred inequality residual variance from one observation to another observation. Based on the test result, heteroscedasticity does not occur in the scatterplot (Figure 1), which is identified in the following analysis: Data points spread above, under, or around zero; Data points do not accumulate above or below it; The spread of the data points do not form a wavy pattern, widened then narrowed and widened again; The spread of the data points does not have a pattern.

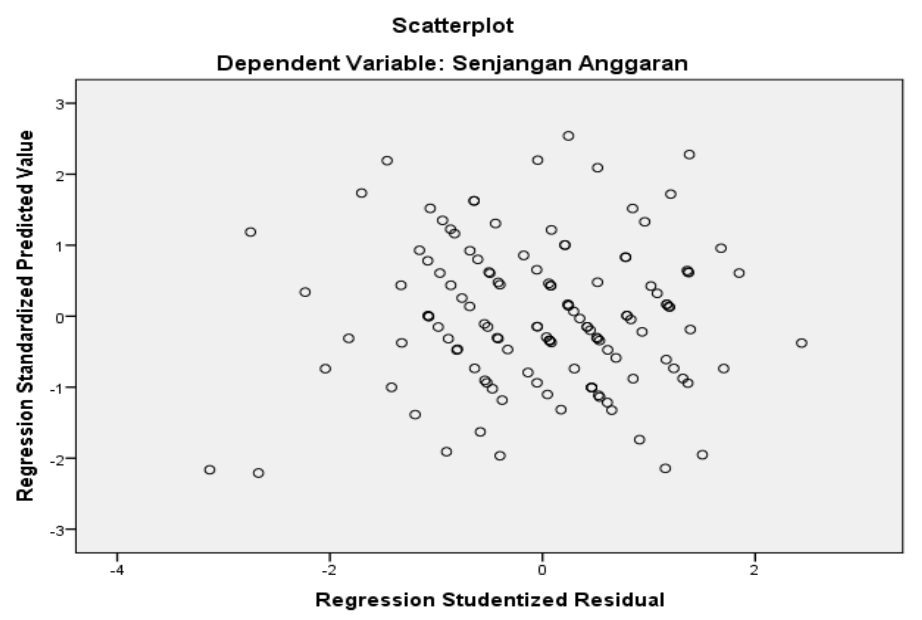

Figure 1 - Heteroscedasticity Test (Output SPSS)

Normality Test aims to test whether the regression model or residual confounding variables have a normal distribution. One way to see the residual normality is to observe normal probability plots comparing the cumulative distribution by a normal distribution. Normal distribution forms a straight diagonal line, and residual plotting the data will be compared with the diagonal line. If the data were normally distributed, then the line that describes the actual data will be normal. Based on the assessment result, the probability plot meets the criteria of normality, therefore it can be concluded that the regression model meets the assumption of normality.

Multiple regression test results presented in Table 1 indicates that the value of $R$ square is at 0263 which means that equation describes the budgetary slack influenced by organizational culture and organizational commitment amounted to $26.3 \%$, while $73.7 \%$ is explained by other factors not included in this study.

Table 2 - Variable Regression Analysis Research

\begin{tabular}{|c|c|c|c|c|c|c|c|c|c|}
\hline \multicolumn{10}{|c|}{ Model Summary ${ }^{b}$} \\
\hline \multirow[b]{2}{*}{ Model } & \multirow[b]{2}{*}{$\mathrm{R}$} & \multirow[b]{2}{*}{$\mathrm{R}$ Square } & \multirow[b]{2}{*}{$\begin{array}{l}\text { Adjusted R } \\
\text { Square }\end{array}$} & \multirow[b]{2}{*}{$\begin{array}{l}\text { Std. Error of } \\
\text { the Estimate }\end{array}$} & \multicolumn{5}{|c|}{ Change Statistics } \\
\hline & & & & & $\begin{array}{l}\text { R Square } \\
\text { Change }\end{array}$ & F Change & df1 & df2 & Sig. F Change \\
\hline 1 & $.513^{\mathrm{a}}$ & .263 & .245 & 2.14541 & .263 & -14.634 & 3 & 123 & .000 \\
\hline
\end{tabular}

Predictors (Constant) Organization Commitment, Budget Participation, and Organization Culture. Dependent Variable: Budgetary slack.

Source: Primary data processed in 2016 (SPSS output). 
$F$ test aims to show whether all the independent variables included in the model have an influence on the independent variable. Multiple regression results indicate significance level of 0.000 (significant), which means that all variables included in the model together affect the budgetary slack. F Test results are exhibited in the following Table 3.

Table 3 - Variable Regression Analysis Research

\begin{tabular}{|c|c|c|c|c|c|c|}
\hline \multicolumn{7}{|c|}{ ANOVA ${ }^{a}$} \\
\hline & & $\begin{array}{l}\text { Sum of } \\
\text { Squares }\end{array}$ & df & Mean Square & $\mathrm{F}$ & Sig. \\
\hline \multirow[t]{3}{*}{1} & Regression & 202.076 & 3 & 67.359 & -14.634 & $.000^{\mathrm{b}}$ \\
\hline & Residual & 566.144 & 123 & 4.603 & & \\
\hline & Total & 768.220 & 126 & & & \\
\hline
\end{tabular}

Predictors (Constant) Organization Commitment, Budget Participation and Organization Culture. Dependent Variable: Budgetary slack.

Source: Primary data processed in 2016 (SPSS output).

The first hypothesis states that budget participation negatively affects budgetary slack. The test results using multiple regression exhibited significance of 0.000 with the direction of the relationship is negative. It means that more employees are involved or participate in the budget process would decrease budgetary slack.

The second hypothesis states that organizational commitment negatively affects Budget. Assessment result with multiple regression test exhibits a negative direction with a significance level of 0.018 , which indicates significant effect. The employees are committed to the organization. The employee exhibits budgetary slack tendency to decline poor organizational culture that exists in or around the work environment which in turn increases budgetary slack.

The third hypothesis states that the organizational culture negatively affects budgetary slack. Assessment result with multiple regression exhibited a negative relationship with a significance level of 0.001 , which means significant. These results indicate that a good organizational culture will reduce budgetary slack.

The fourth hypothesis states that organizational culture moderates the relationship between budgetary participation and budgetary slack. Multiple regression results exhibited a significance level of 0.019 with a negative relationship, this means that organizational culture is a moderating variable but weakens the relationship between budgetary participation and budgetary slack.

The fifth hypothesis states that organizational commitment moderate the relationship between budgetary participation and budgetary slack. Multiple regression results show a negative correlation of 0.01 which means that organizational commitment is a moderating variable but does not strengthen the relationship between budgetary participation and budgetary slack.

\section{CONCLUSION}

Participation Budget has a negative effect on budgetary slack, which indicates employees participating in budget preparation would decline the budgetary slack. Organizational Commitment negatively affects the budgetary slack. Better organization commitment would decrease budgetary slack. Organizational culture negatively affects budgetary slack. Better organizational culture decreases budgetary slack. Organizational culture and organizational commitment is a moderating variable but have a significant negative relationship on both variables. It weakens the relationship between budgetary participation and budgetary slack.

\section{REFERENCES}

1. Anthony, R.N. 2004. Management Control System, Eleventh edition. McGraw-Hill Co. 
2. Asringati, 2006. Pengaruh Komitmen Organisasi dan Ketidakpastian Lingkungan Terhadap Hubungan Partisipas I Anggaran dengan Senjangan Anggaran. Tesis tidak diterbitkan. Universitas Islam Indonesia. Yogyakarta.

3. Bastian, I.2010. Akuntansi Sektor Publik: Suatu Pengantar. Edisi Ketiga. Erlangga, Jakarta.

4. Brownell, P. 1982. Participation in The Budgeting Process.When it Works and When Doesn't.Journal Accounting Literature, Vol 1.

5. Camman, C. 1976. The Effects of the use of Control System. Accounting Organization and Society. Vol 4:301-313.

6. Curtis, S \& Wright D. 2001. Retaining Employees - The Fast Track to Commitment, Management Research News, Vol. 24.

7. Dunk, A.S. 1993. The Effect of Budget Emphasis and Information Asymmetry on Relation Between Budgetary Participation and Slack. The Accounting Review.

8. Durkin, M. 1999. Employee Commitment in Retail Banking: Identifying and Exploring Hidden Dangers, International Journal of Bank Marketing, Vol 17. 3: 124-134.

9. Ghozali, I. 2009. Aplikasi Multivariate dengan Program SPSS. Semarang: Badan Penerbit Universitas Diponegoro.

10. Govindarajan, V. 1986. Impact of Participation in the Budgetary Process on Manajerial Attitudes and Perfomance Universalistic and Contigency Prespective. Decision Science, 17:496-516.

11. Gujarati, D. 2006. Dasar - DasarEkonometrika. Erlangga.

12. Ernawaty, U., 2012. Analisis Budaya Organisasi dan Asimetri Informasi dalam Senjangan Anggaran. Jurnal Akuntansi Multiparadigma, Vol. 3 No. 3, pp. 334-501.

13. Hansen, D.R \& Mowen, M.M. 2007. Management Accounting. USA: South-Western College Publishing.

14. Hofstedet G, Nevijen B, Ohayv DD, Sunders G. 1990. Measuring Organizational Cultures: A Qualitative and Quantitative Study across Twenty Cases. Administrative Science Quarterly, 35 (1990): 286-316.

15. Hofstede G. 1994. Cultures And Organizations. Software of the Mind. Harper Collins Publishers, London.

16. Jogiyanto. 2007. Metodologi Penelitian Bisnis: Salah Kaprahdan PengalamanPengalaman. BPFE, Yogyakarta.

17. Lowe, E.A. \& Shaw, R.W. 1968. An analysis of Managerial Biasing: Evidence from a Company's Budgeting Proces. The Journal of Management Studies: $304-315$.

18. Luthans, F. 1998. Organizational Behavior.Irwin McGraw-Hill, USA.

19. Mardiasmo, 2009.AkuntansiSektorPublik. Edisi IV. Andi Offset. Yogyakarta.

20. Merchant, K.A. 1981.The Design of The corporate Budgeting System: Influence on Managerial Behaviour and Performance. The Accounting Review.

21. Murray. D. 1990. The Performance Effects of Participative Budgeting: An Integration of Intervening dan Moderating Variables. Behavioral Research in Accounting, 2: 104-123.

22. Nouri, H. \& R. J. Parker. 1996. "The Effect of Organizational Commitment on Relation Between Budgetary Participation and Budgetary Slack". Behavioral Research In Accounting. Vol 8.74-90.

23. Onsi, M. 1973. Factor Analysis of Behavioural Variables Affecting Budgetary Slack.The Accounting Review:535-548.

24. Ritongan, P. 2008, Pengaruh Budaya Paternalistik dan Komitmen Organisasi Terhadap Hubungan Partisipasi Anggaran dan Kinerja Manajerial Pada PDAM Tirtanindi Sumatera Utara, Tesis tidak diterbitkan, Universitas Sumatera Utara.

25. Sulaksono T, 2005. Budaya Organisasidan Ketidakpastian Lingkungan Dalam Hubungan Gaya Evaluasi Atasan Terhadap Tekanan Kerjadan Kepuasan Kerja Bawahan, Tesistidakditerbitkan, Semarang, Universitas Diponegoro.

26. Supanto, 2010, Analisis Pengaruh Partisipasi Anggaran Terhadap Senjangan Anggaran dengan Motivasi, Budaya organisasi dan Asimetri Informasi Sebagai Variabel Moderating, Tesistidakditerbitkan, Universitas Diponegoro. 
27. Supomo, B \& Indriantoro. 1998. Pengaruh Struktur dan Kultur Organisasional terhadap Keefektifan Anggaran Partisipatif dalam Meningkatkan Kinerja Manajerial. Studi Empiris pada Perusahaan Manufaktur Indonesia.Kelola, No.18:61-84.

28. Tjahjaning, P. 2011. Pengaruh Partisipas iPenyusunan Anggaran Terhadap Kinerja Manajerial dengan Budaya Organisasi dan Motivasi Sebagai Variabel Moderating, Tesis tidak diterbitkan, Universitas Diponegoro.

29. Young, S.M. 1985. Participative Budgeting: The Effect of Risk Aversion and Asymmetric Information on Budgeting Slack.Journal of Accounting Research:829-842.

30. Zurnali, C. 2010, "Learning Organization, Competency, Organizational Commitment, dan Customer Orientation: Knowledge Worker - Kerangka Riset Manajemen Sumber Daya Manusia di Masa Depan", PenerbitUnpad Press, Bandung. 